Paper

\title{
Crystal orientation control of antimony telluride thermoelectric thin films by oblique deposition
}

\section{アンチモン・テルル熱電薄膜の斜め蒸着法による配向性制御}

\author{
Takuya SHIMOJO, Yusuke SASAKI and Masayuki TAKASHIRI \\ Department of Materials Science, Tokai University, 4-1-1 Kitakaname, Hiratsuka, Kanagawa, \\ 259-1292 Japan \\ TEL: +81-463-58-1211(EX.4203) FAX: +81-463-50-2096 e-mail: takashiri@tokai-u.jp \\ (Received 14 March, $2016 \quad$ Accepted 30 August, 2016)
}

\begin{abstract}
We prepared p-type antimony telluride thin films by an oblique deposition at the incident angle ranging from $0^{\circ}$ to $80^{\circ}$. We investigated the relationship between the structural and electrical properties of the thin films. As the structural properties, we analyzed cross-section morphology by scanning electron microscope (SEM), and the crystal orientation and crystallite size by x-ray diffraction (XRD) analysis. As the electrical properties, we measured in-plane electrical conductivity, Seebeck coefficient and power factor at room temperature. As a result, we found the thin film at the incident angle of $40^{\circ}$ obtained the highest crystal orientation. As the incident angle increased, the crystallite size were enhanced but the power factor decreased. The power factor of thin film at the incident angle of $0^{\circ}$ was $1.26 \mu \mathrm{W} /\left(\mathrm{cm} \cdot \mathrm{K}^{2}\right)$ and thin film at the incident angle of $80^{\circ}$ was $0.38 \mu \mathrm{W} /\left(\mathrm{cm} \cdot \mathrm{K}^{2}\right)$.
\end{abstract}

Keywords : Antimony telluride thin films, Oblique deposition, Crystal orientation control

\section{INTRODUCTION}

製造業や電気・ガス・熱供給業などの日本の産業が排 出する利用可能な低温排熱エネルギーの大半は再利用さ れずに排気されているのが現状である. その排熱エネル ギーを再利用する方法の一つとして，熱電材料を用いた 熱電発電が挙げられる. 熱電発電は工場の排熱などの未 利用な熱を電気に直接変換できる長所がある.しかし, 熱電発電は熱を電気に変換する性能が十分でないため実 用化に至っていない. よって, 熱電材料の熱電変換性能 向上が今後の課題となっている.

熱電変換性能の評価方法の一つとしてパワーファクタ 一(P.F.)があり, 以下の式で求められる.

$$
P . F .=S^{2} \sigma .
$$

式 (1) の $S$ はゼーベック係数, $\sigma$ は電気伝導率を示す. 式（1）から, パワーファクターはゼーベック係数と電 気伝導率に比例関係にあることが読み取れる。つまり， ゼーベック係数と電気伝導率の性能向上がパワーファク ターの性能向上に繋がるという形になる.

今回, 我々は熱電材料の性能向上方法の 1 つとして, 配向性制御に注目した。配向性は, 結晶内にある結晶粒
がある方位へ優先的に成長する様子を示しており，同じ 方位へ成長した結晶は配向性が比較的高いと見なせる。 逆に, 多結晶のような, それぞれ異なった方位へ成長し た結晶は配向性が比較的低いと見なされる。その多結晶 のような配向性が低い結晶は，それぞれ異なった方位で 成長した結晶が集合している為，方位のズレによる結晶 粒界が作られやすくなる，その結晶粒界は電気抵抗を生 じる為, 電気伝導率の減少につながる. よって, その粒 界の対策の 1 つとして配向性制御が挙げられ，その制御 が熱電材料の性能向上につながるかどうか研究が進めら れている。 1

今回の研究は $\mathrm{p}$ 型であるアンチモン・テルル $(\mathrm{Sb}-\mathrm{Te})$ 薄膜の斜め蒸着法による配向性制御から電気伝導率を向 上させることを目的として研究を進めた．また，配向性 と電気的特性の関連性も探ることを目的とした。

薄膜熱電材料の成膜方法の代表例として，スパッタリ ング法, ${ }^{2}$ めっき法, ${ }^{3}$ フラッシュ蒸着法 ${ }^{4}$ などがある. 中でもスパッタリング法は低コストで薄膜を作製でき, かつ，基板への付着力が強い.また，合金や化合物の夕 ーゲットの組成比をほぼ同じ状態に保ちながら膜を作製 
することが可能である．よって，スパッタリング法を用 いて斜め蒸着法による配向性制御の研究を進めた.

斜め蒸着法は, ターゲットの原子・分子を基板へ斜め に入射させる方法のことを指す. ${ }^{5-6}$ 斜めに入射させるこ とによって, 基板上でのターゲットの原子・分子の付着 のしやすさに変化が生まれる. 付着しやすい部分はその まま結晶成長をするが, 付着しにくい部分, いわゆる『日 陰』の部分はあまり結晶成長をしない為, 空隙や孔を作 る. その『日陰』の部分が生じることを自己遮蔽効果と 呼ぶ. その自己遮蔽効果によって結晶は柱状構造を作る という形になる. その様子を Fig. 1 に示す.

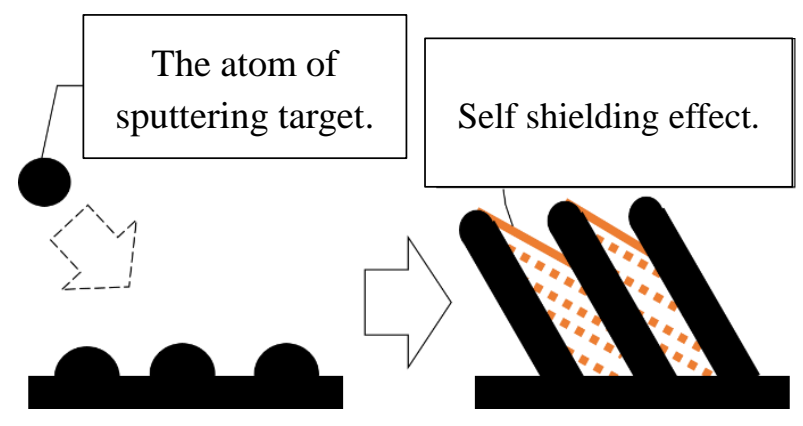

Fig. 1. Schematic diagram of oblique deposition and self shielding effect.

また，自己遮蔽効果によって結晶の成長できる方向や 範囲が限られてくる為, その現象を用いることで配向性 制御を行うことができるのではないかと考えた.

\section{EXPERIMENTAL}

まず, $\mathrm{p}$ 型 $\mathrm{Sb}-\mathrm{Te}$ 薄膜を $\mathrm{RF}$ マグネトロンスパッタリン グ装置(Tokuda, CFS-8EP)を用いて成膜した. ターゲット は直径 5 インチの純度 99.9\%の Sb(40 at.\%)-Te(60 at.\%)(高 純度科学研究所製)を用いた。 基板はガラス基板(EAGLE XG)(縦 : $30 \mathrm{~mm}$, 横 : $20 \mathrm{~mm}$, 厚さ: $1.1 \mathrm{~mm}$ )を使用した. そのガラス基板は角度の付いた斜方土台 $\left(0^{\circ}, 20^{\circ}, 40^{\circ}\right.$, $\left.60^{\circ}, 80^{\circ}\right)$ にカプトンテープで $40 \mathrm{~mm}^{2}$ になるように面積 制御しながら固定した. 基板へのターゲット原子・分子 の直進性を高めさせる為に囲いを付けた. その様子を Fig. 2 に示す. 囲いを付けた後, RF マグネトロンスパッタリ ング装置内にカプトンテープで固定した.

成膜条件は, 雰囲気ガスは高純度 Ar ガスを用い, 成 膜圧力は $1.0 \mathrm{~Pa}$ とした. 印加 $\mathrm{RF}$ パワーは $200 \mathrm{~W}$ とし, 基板加熱は行わなかった. 成膜時間は 120 分に固定し, 自己遮蔽効果をより引き起こす為に回転なしの条件で成 膜をした。

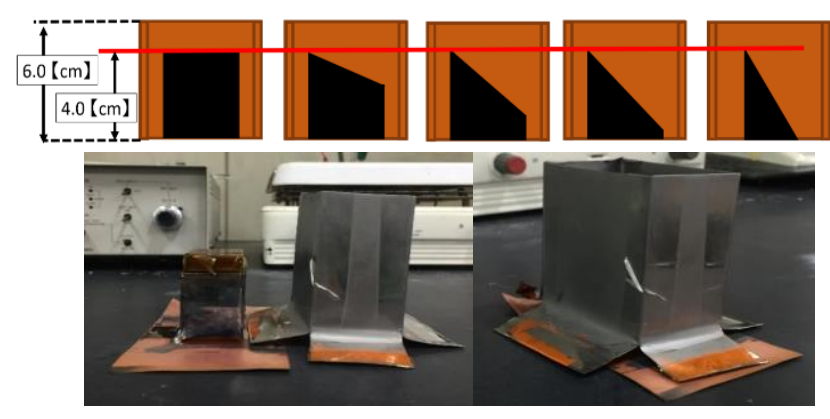

Fig. 2. Cross-section view images of the oblique deposition and the appearance photographs.

作製した試料の構造的特性として走査型電子顕微鏡 (SEM, S-4800, Hitachi)による断面観察と X 線回折による 配向性と結晶子サイズ評価した。

電気的特性として電気伝導率 $\sigma$, ゼーベック係数 $S$ と パワーファクターP.F. $\left(P . F .=S^{2} \sigma\right)$ を室温で評価した. 電気 伝導率の值は，4 探針法抵抗測定装置(NAPSON, RT-70V) による電気抵抗值を用いて算出した。 ゼーベック係数の 值は，ヒートシンクとヒーターの間に作製した試料を置 き，その表面に $\mathrm{K}$ 熱電対を固定し，膜面方向に温度差を 0〜 $4 \mathrm{~K}$ を与えた時に発生する熱起電力から算出した. 得 られた熱起電力には $\mathrm{K}$ 熱電対の材料であるアルメルとク ロメルの熱起電力を含んでいる為, その分を差し引いて 熱電薄膜のみのゼーベック係数を算出した. パワーファ クターP.F.は得られた電気伝導率 $\sigma$ とゼーベック係数 $S$ から算出をした。

\section{RESULTS AND DISCUSSION}

Fig. 3 に Sb-Te 薄膜の縦断面 SEM 観察部分を示す.こ の観察では自己遮蔽効果による膜内構造を観察したい為, Fig. 3 に示した部分の破断面をSEM で観察した.

Fig. 4 に Sb-Te 薄膜の縦断面 SEM 像を示す. 各角度の 試料の膜厚がそれぞれ異なっている様子が見られた. 角 度が $0 \circ$ の時の膜は縦断面 SEM 像の中で最も厚く, 隣接 した結晶同士が結合し合いながら上向きに成長している 様子が見られた. $20^{\circ}$ の薄膜からは結晶の合間に空隙のよ うな様子が見られた. $40^{\circ}$ の薄膜は中心付近に斜めに堆積 している様子が見られた. $60^{\circ}$ の薄膜から斜めに堆積した 柱状構造が部分的に見られたが，基板付近は隣接した結 晶が結合し合って 1 つの層のようになっている様子が見 られた. $80^{\circ}$ の薄膜は縦断面 SEM 像の中で最も薄く, 斜 めに堆積している様子が見られた. 


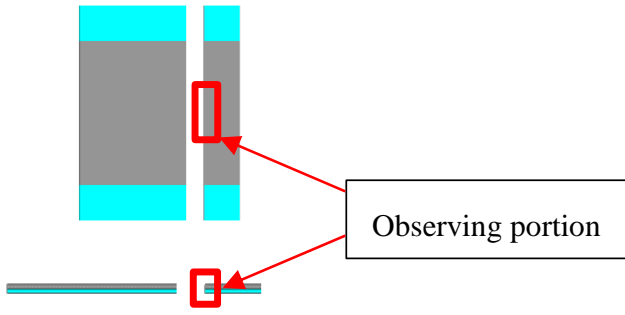

Fig. 3. Observing portion of cut out section of $\mathrm{Sb}-\mathrm{Te}$ thin films on glass substrates by SEM.
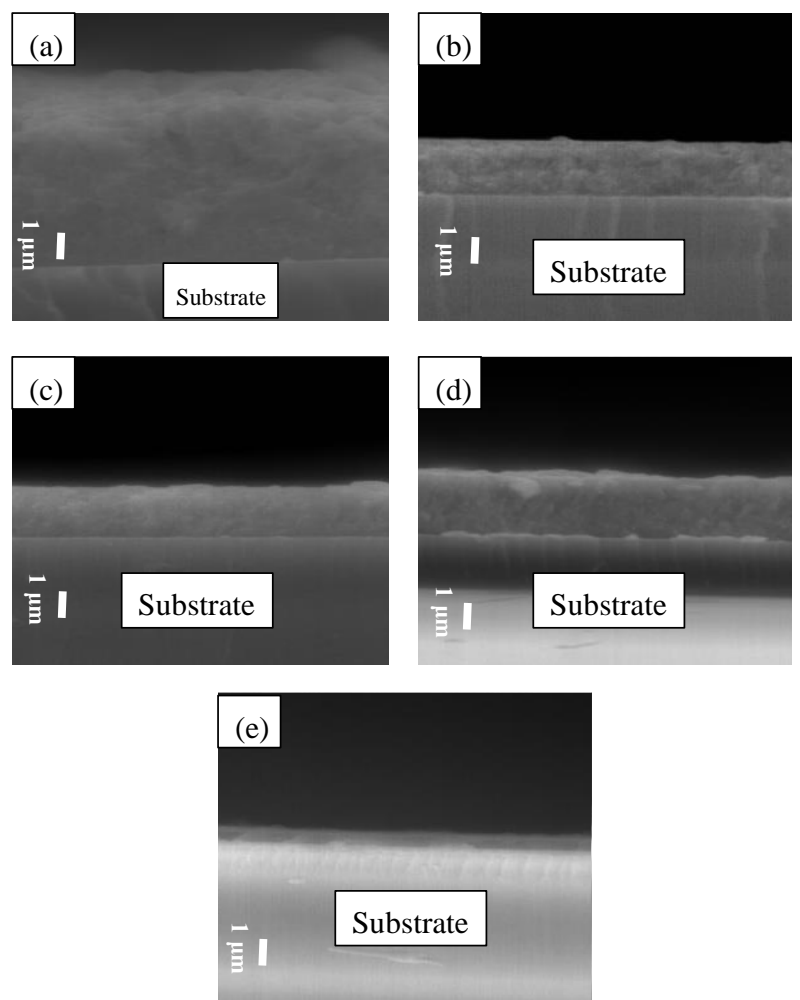

Fig. 4. Cross-section of oblique deposited Sb-Te thin films on glass substrates imaged using SEM, oblique angles: (a) $0^{\circ}$, (b) $20^{\circ}$, (c) $40^{\circ}$, (d) $60^{\circ}$, (e) $80^{\circ}$.

この SEM 観察像から, 角度が増加するにつれて膜内 に空隙が作られたり，柱状構造が作られたりしている様 子が見られた。よって，今回作製した試料は自己遮蔽効 果が起きた可能性が高いと考えられる.

$60^{\circ}$ の試料の膜内構造に注目してみると, ガラス基板付 近は隣接した結晶同士が結合し合って1つの層になって おり, 膜の中心に近づくにつれて層から柱状構造が成長 していく様子が見られた．今回の実験はターゲットの原 子・分子が斜めに入射している為, 自己遮蔽効果が起き やすくなることから，基板付近の膜は不均一に成長する 可能性がある. よって, 基板付近の層はアモルファスの ような層になっていることが考えられる。

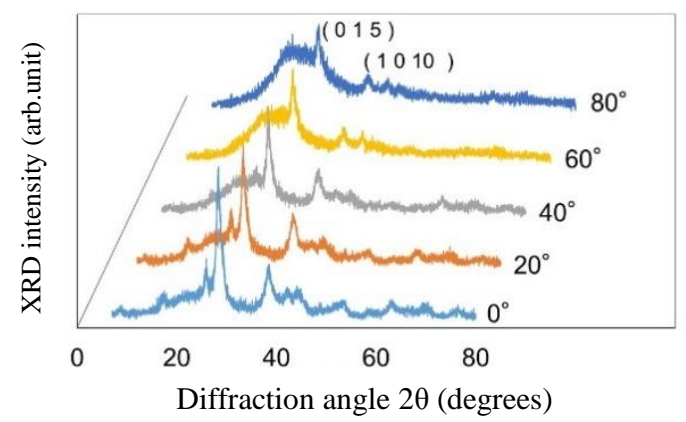

Fig. 5. X-ray diffraction patterns of Sb-Te thin films.

Fig. 5 に Sb-Te 薄膜の X 線回折結果を示す. 試料全て の最大回折ピークの面指数は(（０１１５）であることが分か った.

Fig. 5 の結果をもとに( 015 ) ピークの配向性を算出し, Fig. 6 にまとめた。 その Fig. 6 の結果から，40の時の試 料が最も配向性が高い様子が示された. この結果から, 斜め蒸着法を用いて配向性を向上させることは比較的可 能であると考えられる.

$c$ 軸のみに配向させた配向制御膜を作製したい場合, 斜方土台の角度の調整や高温環境下での試料作製などと いった改善が必要になると思われる.

Fig. 7 に基板角度と結晶子サイズの関係を示す. 結晶 子サイズは X 線回折結果から得られた( $\left.0 \begin{array}{lll}0 & 1 & 5\end{array}\right)$ の回折ピ ークの半值幅から算出した。 その結果，角度増加と共に 結晶子サイズも拡大していく様子が見られた.

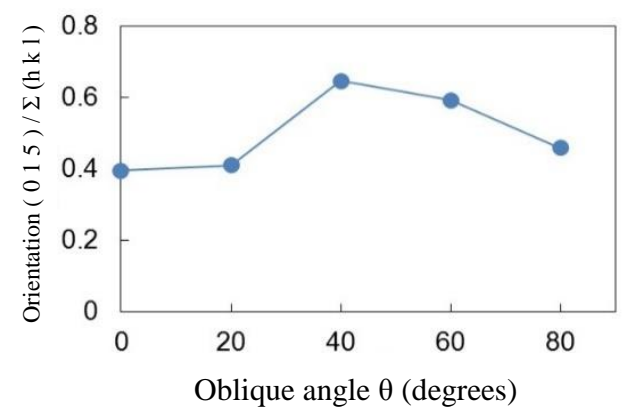

Fig. 6. Orientation $\left(\begin{array}{lll}0 & 1 & 5\end{array}\right) / \sum(\mathrm{h} k 1)$ of Sb-Te thin films.

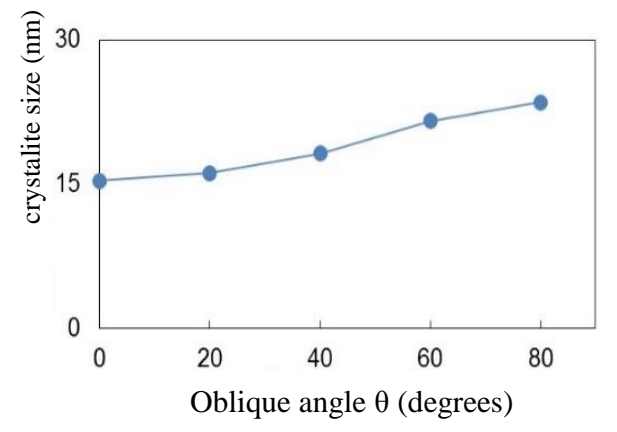

Fig. 7. Crystallite size of Sb-Te thin films. 


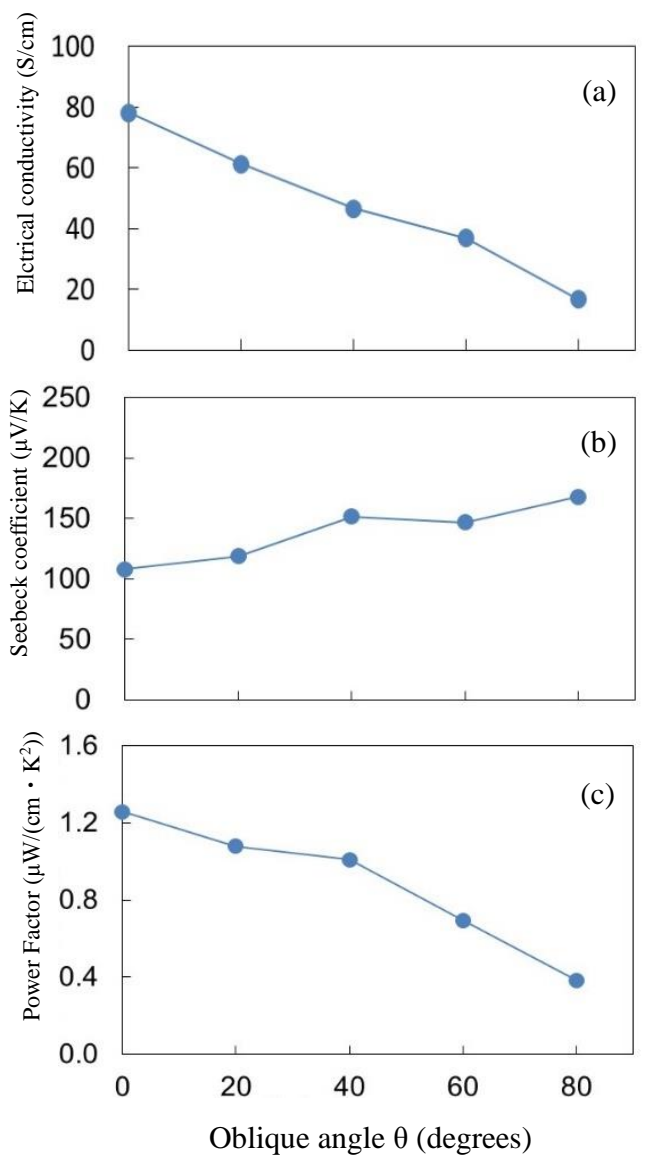

Fig. 8. (a) Electrical conductivity, (b) Seebeck coefficient, (c) Power factor of $\mathrm{p}$ type $\mathrm{Sb}-\mathrm{Te}$ thin films.

角度増加と共に結晶子サイズも拡大していることから， 斜め蒸着法を用いた結晶子サイズ向上は可能であると考 えられる。

Fig. 8 にSb-Te 薄膜の電気伝導率 $\sigma$, ゼーベック係数 $S$, パワーファクターP.F. の基板角度依存性を示す. 電気伝 導率は角度増加と共に減少し, 逆にゼーベック係数は増 加していく様子が見られた。これは自己遮蔽効果による 空隙がその一因である思われる. パワーファクターは角 度増加と共に減少するという結果になった。

Fig. 8(a) の電気伝導率のグラフでは, 角度増加と共に 減少している様子が見られた。この結果から, 斜め蒸着 法による空隙や孔が電気伝導率を減少させたのではない かと考える.この他, 斜めに入射されたターゲット原子・ 分子はガラス基板付近では上手く結合出来ない可能性が ある為, 基板付近は結晶性の低い層, いわゆるアモルフ アスの層になっていることが予想される.

Fig. 8 (b) のゼーベック係数のグラフでは, 電気伝導率 とは逆の傾向が見られた。これは角度増加による空隙や
空孔の影響によってキャリア濃度の差も大きくなったの ではないかと考える。

最後に Fig. 8 (c) のパワーファクターのグラフでは, 角 度増加と共に減少していく様子が見られた。この結果か ら, 斜め蒸着法による熱電材料の電気的特性向上は比較 的厳しいことが予想される.

\section{CONCLUSION}

今回の研究は RF マグネトロンスパッタリング装置と 角度の付いた斜方土台を用いて, P 型 Sb-Te 系薄膜の斜 め蒸着膜の試料を作製した。作製後, 電気的特性と構造 的特性を観察した. その結果, 角度が増加すると共に結 晶子サイズは増加し, パワーファクターは減少すること が分かった．配向性は $40^{\circ}$ の試料が最も高いことが分か った.これは斜め蒸着法による自己遮蔽効果によって空 隙や空孔が作られたことによるものだと考えられる．配 向性の場合は自己遮蔽効果による空隙や空孔によって結 晶の成長方向に制限ができたため，配向性が比較的整い やすい環境になったのだと思われる。この結果を踏まえ た上で断面 SEM 観察を行った結果, 各角度の試料の膜 厚が異なることも分かった．また，40の試料から膜内構 造の一部に柱状構造のような部分が見られ, かつ, 斜め に堆積している様子が見られた。この結果から, 角度増 加と共に膜厚が減少し, 自己遮蔽効果が起こりやすくな っていることが予想される.

\section{ACKNOWLEDGEMENTS}

本研究の薄膜の評価・分析に協力していただいた東海 大学の喜友名浩史氏, 宮本泰男氏, 初田直樹大学院生に 感謝する.

\section{REFERENCES}

${ }^{1}$ M. Takashiri, S. Tanaka and K. Miyazaki, Thin Solid Films, 519, 3525 (2010).

${ }^{2}$ K. Kusagaya, H. Hagino, S. Tanaka, K. Miyazaki and M. Takashiri, J. Electron. Mater., 44, 1632 (2015).

${ }^{3}$ K. Matsuoka, M. Okuhata and M. Takashiri, J. Alloys Compd, 649, 721 (2015).

${ }^{4}$ M. Takashiri, S. Tanaka and K. Miyazaki, J. Electron. Mater., 43, 1881 (2014).

5 J. C. Sit, D. Vick, K. Robbie and M. J. Brett, J. Mater. Res., 14, 1197 (1999).

${ }^{6}$ L. Abelmann and C. Lodder, Thin Solid Films, 305, 1 (1997). 